JOURNAL

OF TOURISM

AND ECONOMIC
Journal of Tourism and Economic Vol.4, No.2, 2021, Page 135-152

ISSN: 2622-4631 (print), ISSN: 2622-495X (online)

Email: jurnalapi@gmail.com

Website: http://jurnal.stieparapi.ac.id/index.php/JTEC

DOI: https://doi.org/10.36594/jtec.v4i2.123

\title{
STRATEGI PENGEMBANGAN DAYA TARIK WISATA BANGSRING UNDERWATER BERBASIS MASYARAKAT
}

\author{
Muhammad Ridla \\ Program Studi DIV Manajemen Bisnis Pariwisata, Politeknik Negeri Banyuwangi \\ Kanom \\ Program Studi DIV Manajemen Bisnis Pariwisata, Politeknik Negeri Banyuwangi \\ kanom@poliwangi.ac.id \\ Randhi Nanang Darmawan \\ Program Studi DIV Manajemen Bisnis Pariwisata, Politeknik Negeri Banyuwangi
}

\begin{abstract}
Bangsring Underwater is one of the natural tourism attractions in Banyuwangi. Located in Bangsring village, Wongsorejo subdistrict, Banyuwangi regency. Bangsring Underwater is known for its underwater natural beauty that continues to be maintained and developed by community. The aims of the study are: 1) to find out what are the supporting factors and inhibitory factors in the development of community-based Bangsring Underwater tourism attraction. 2) find out of strategy of developing community-based tourism. Data collecting are observations, in-depth interviews, and documentation. By using SWOT as data analysis tools in the form of (Strength, Weakness, Opportunities And Threats). The results of this study found the presence of several supporting factors such as; a) supported by the local government, $b$ ) the village government of Bangsring, c) the tourism conscious group Samudra Bhakti (pokdarwis Bangsring Underwater) in the development of the attraction of Bangsring Underwater. And factors several inhibitory factors such as; a) lack of human resources and b) some surrounding communities that have not been able to accept the existence of tourism activities in the tourist attraction Bangsring Underwater. In addition, this study also found seven alternative strategies obtained from SWOT analysis resulted in seven such strategies; (SO) tourism attraction development strategy, and tourism attraction promotion strategy. (WO) strategy improves safety and comfort. (ST) strategy to improve the quality of the environment, and sustainable tourism development strategy. (WT) human resource development strategy, and strategy to increase cooperation with elements of government and private partnerships.
\end{abstract}

Keywords: development strategy, tourist attraction, community based tourism 


\begin{abstract}
ABSTRAK
Bangsring Underwater merupakan daya tarik wisata yang berlokasi di Desa Bangsring Kecamatan Wongsorejo Kabupaten Banyuwangi. Bangsring Underwater merupakan kawasan konservasi terumbu karang dan biota laut yang dikelola langsung oleh kelompok sadar wisata dan masyarakat sekitar Desa Bangsring. Tujuan penelitian ini adalah: 1) untuk mengetahui apa saja faktor pendukung dan faktor penghambat dalam pengembangan daya tarik wisata Bangsring Underwater berbasis masyarakat. 2) mengetahui strategi pengembangan daya tarik wisata Bangsring Underwater berbasis masyarakat. Penelitian ini menggunakan pendekatan deskriptif kualitatif. Teknik pengumpulan data dengan observasi, wawancara mendalam, dan dokumentasi. Melalui alat analisis SWOT data berupa (Strength, Weakness, Opportunities Dan Threats). Hasil dari penelitian ini ditemukan adanya beberapa faktor pendukung seperti; a) didukung oleh pemerintah daerah, b) pemerintah desa Bangsring, c) kelompok sadar wisata Samudra Bhakti (pokdarwis Bangsring Underwater) dalam pengembangan daya tarik Bangsring Underwater. Dan faktor beberapa faktor penghambat seperti; a) minimnya sumber daya manusia dan b) beberapa masyarakat sekitar yang belum bisa menerima adanya kegiatan kepariwisataan di daya tarik wisata Bangsring Underwater. Selain itu penelitian ini juga terdapat tujuh strategi alternatif yang diperoleh dari analisis SWOT seperti; (SO) strategi pengembangan daya tarik wisata, dan strategi promosi daya tarik wisata. (WO) strategi meningkatkan keamanan dan kenyamanan. (ST) strategi meningkatkan kualitas lingkungan, dan strategi pengembangan pariwisata berkelanjutan. (WT) strategi pengembangan sumber daya manusia, dan strategi meningkatkan kerjasama dengan unsur kemitraan pemerintah maupun swasta.
\end{abstract}

Kata Kunci: strategi pengembangan, daya tarik wisata, pariwisata berbasis masyarakat 


\section{PENDAHULUAN}

Indonesia merupakan salah satu negara yang berkembang di dunia yang memiliki potensi destinasi wisata sangat besar, maka dari itu jika dilakukan pengelolaan dan pengembangan yang tepat dengan mengedepankan kolaborasi, inovasi , serta keterlibatan masyarakat maka potensi tersebut dapat dikembangkan menjadi sumber perekonomian yang dapat meningkatkan devisa negara. Banyuwangi merupakan salah satu Kabupaten yang berada di ujung timur Pulau Jawa yang terkenal dengan keindahan pantai, alam, dan juga budaya membuat popularitas Kabupaten Banyuwangi semakin mendunia seiring dengan perkembangan pada sektor pariwisatanya yang semakin pesat (Kanom, Nurhalimah, \& Darmawan, Recovery Pariwisata Banyuwangi Pasca Covid 19, 2020). Keindahan alam dan budaya tersebut merupakan dua hal yang tidak terpisahkan jika dikaitkan dengan Kabupaten Banyuwangi. Melalui Branding Majestic Banyuwangi perkembangan pariwisata Kabupaten Banyuwangi terus melesat dengan cepat sehingga mampu menyamai destinasi-destinasi pariwisata prioritas di Indonesia (Kabupaten Banyuwangi, 2021).

Bangsring Underwater (Bunder) adalah tempat wisata yang berbasis konservasi terumbu karang yang terletak di Desa Bangsring Kecamatan Wongsorejo Kabupaten Banyuwangi. Keindahan Bunder tidak terletak di pantainya, melainkan taman bawah laut yang benar-benar terjaga. Wisatawan dapat melihat banyak ikan hias seperti nemo, untuk melihatnya wisatawan dapat melakukan snorkeling atau diving. Bunder juga terkenal dengan sebutan Rumah
Apung, rumah ini berfungsi untuk klinik ikan dan tempat penangkaran ikan hiu. Bangsring Underwater berkembang secara maksimal dan mulai dikenal oleh masyarakat baik dalam negeri maupun luar negeri. Pandemi Covid 19 mengakibatkan penurunan jumlah wisatawan sehingga para pelaku usaha yang ada pada daya tarik Bangsring Underwater beralih profesi dan mencari pekerjaan lain. Strategi pengembangan daya tarik wisata demi pariwisata berkelanjutan dengan melibatkan masyarakat memang sudah menjadi prioritas baik sebelum Covid maupun pasca Covid 19, dalam artikel ini peneliti juga mengambil rujukan penelitian sejenis yaitu (Kanom \& Zazilah, 2019), (Kanom \& Randhi, 2020) dan (Muliarta, 2020).

Berdasarkan dari permasalahan yang ada, maka dilakukan penelitian untuk dapat merumuskan dan memformulasikan strategi yang relevan. Adapun fokus dari penelitian ini adalah strategi pengembangan pariwisata berbasis masyarakat di daya tarik wisata Bangsring Underwater. Tujuan dari penelitian ini adalah untuk mengetahui faktor pendukung dan faktor penghambat serta merumuskan strategi yang tepat untuk diterapkan dalam pengembangan pariwisata berbasis masyarakat di daya tarik wisata Bangsring Underwater. Hasil penelitian ini diharapkan dapat menjadi masukan serta referensi tambahan untuk pengembangan pariwisata berbasis masyarakat di daya tarik wisata Bangsring Underwater, tepatnya di Desa Bangsring Kecamatan Wongsorejo Kabupaten Banyuwangi Provinsi Jawa Timur. 


\section{TINJAUAN LITERATUR}

Berdasarkan Undang-Undang Republik Indonesia Nomor 10 Tahun 2009 tentang kepariwisataan bahwa pariwisata merupakan bagian integral dari pembangunan nasional yang dilakukan secara sistematis, terencana, terpadu, berkelanjutan, dan bertanggung jawab dengan tetap memberikan perlindungan terhadap nilai-nilai agama, budaya yang hidup dalam masyarakat, kelestarian dan mutu lingkungan hidup, serta kepentingan nasional. Pembangunan kepariwisataan diperlukan untuk mendorong pemerataan kesempatan berusaha dan memperoleh manfaat serta mampu menghadapi tantangan perubahan kehidupan lokal, nasional, dan global. Menurut Simanjuntak et al (2017) pariwisata sebagai fenomena perjalanan manusia secara perorangan atau kelompok dengan berbagai macam tujuan asalkan bukan mencari nafkah atau menetap.

Berdasarkan Undang-Undang Nomor 10 Tahun 2009, daya tarik wisata dijelaskan sebagai segala sesuatu yang memiliki keunikan, kemudahan, dan nilai yang berupa keanekaragaman kekayaan alam, budaya, dan hasil buatan manusia yang menjadi sasaran atau kunjungan wisatawan.

Strategi merupakan alat untuk mencapai tujuan perusahaan dalam kaitannya dengan tujuan jangka panjang, program tindak lanjut, serta prioritas alokasi sumber daya. Moekidjat, (2005) pengembangan adalah perubahan yang dilakukan oleh seorang ataupun kelompok untuk mengarahkan pada perbaikan dan perubahan itu harus berdasarkan pada pengetahuan, kecakapan dan sikap yang diwujudkan dalam pekerjaan untuk sekarang ini dan untuk dimasa akan datang. Pengembangan pariwisata perlu dijadikan sebagai bagian dari pembangunan nasional yang berkelanjutan.
Pengembangan pariwisata merupakan proses mengembangkan sesuatu yang sudah ada secara terus menerus dari berbagai aktivitas.

Pengembangan pariwisata perlu direncanakan secara menyeluruh dengan berbagai pertimbangan. Pada intinya strategi pengembangan pariwisata yaitu upaya yang dilakukan oleh pihak-pihak yang berkaitan untuk mengorganisasikan kemajuan destinasi wisata dan meningkatkan potensi yang sudah ada untuk menjadi daya tarik wisatawan.

Pariwisata berbasis masyarakat sebagai sebuah pendekatan pemberdayaan yang melibatkan dan meletakkan masyarakat sebagai pelaku penting dalam konteks paradigma baru pembangunan yakni pembangunan yang berkelanjutan (sustainable development) paradigma pariwisata berbasis masyarakat merupakan peluang untuk menggerakkan segenap potensi dan dinamika masyarakat, guna mengimbangi peran pelaku usaha pariwisata skala besar. Pariwisata berbasis masyarakat tidak berarti merupakan upaya kecil dan lokal semata, tetapi perlu diletakkan dalam konteks kerjasama masyarakat secara global.

Community Based Tourism adalah kegiatan pariwisata yang dimiliki, dioperasikan, dan dikelola atau dikoordinasikan pada masyarakat yang memberikan kontribusi bagi kesejahteraan masyarakat dengan mendukung mata pencaharian yang berkelanjutan dan melindungi nilai tradisi sosial budaya, sumber daya alam dan warisan budaya ( The ASEAN Secretariat, 2016). Community Based Tourism sering diakui sebagai contoh sempurna dari pengembangan pariwisata berkelanjutan. Alasan dari hal ini adalah bahwa partisipasi masyarakat lokal dalam pengembangan dan praktek proyek sangat tinggi, dan bahwa seluruh masyarakat menerima manfaat dari proyek tersebut. Menurut Suansri (2003:14) Community Based Tourism adalah pariwisata yang menitikberatkan keberlanjutan lingkungan, sosial, dan budaya ke dalam satu kemasan. 
Hal ini dikelola dan dimiliki oleh masyarakat, untuk masyarakat, dengan tujuan memungkinkan pengunjung untuk meningkatkan kesadaran mereka dan belajar tentang masyarakat dan lokal cara hidup.

\section{METODE PENELITIAN}

Metode penelitian yang dipakai dalam penelitian ini adalah pendekatan deskriptif kualitatif. Pendekatan penelitian kualitatif adalah metode penelitian yang digunakan untuk meneliti pada kondisi objek yang ilmiah, dimana peneliti adalah sebagai instrumen kunci, teknik pengumpulan data bersifat induktif, dan hasil penelitian kualitatif lebih menekankan pada makna dari pada generalisasi (Sugiyno, 2016). Sedangkan menurut Sumantri (2011) penelitian kualitatif merupakan sejenis penelitian formatif yang secara khusus memberikan teknik untuk memperoleh jawaban atau informasi mendalam tentang pendapat dan perasaan seseorang. Penelitian ini memungkinkan untuk mendapatkan halhal yang tersirat (insight) mengenai sikap, kepercayaan, motivasi dan perilaku target populasi.

Berdasarkan rumusan masalah dan tujuan dalam penelitian ini, peneliti berusaha untuk memperoleh gambaran serta dapat mengetahui dan memahami fenomenafenomena sosial yang terjadi, kemudia merumuskan strategi pengembangan daya tarik wisata berbasis masyarakat pada wisata Bangsring Underwater.

Menurut Sugiyno (2016) pengumpulan data menggunakan sumber primer, dan sumber sekunder. Sumber primer adalah sumber data yang langsung memberikan data kepada pengumpul data, dan sumber sekunder merupakan sumber yang tidak langsung memberikan data kepada pengumpul data. Data primer didapatkan melalui observasi dan wawancara, sedangkan data sekunder didapatkan melalui studi dokumentasi dan studi literatur.

Data yang digunakan dalam penelitian ini adalah data primer, yaitu data yang dikumpulkan melalui pihak pertama, biasanya dapat melalui wawancara, dan jejak. Data primer yang digunakan dalam penelitian ini adalah observasi dan wawncanra semi terstruktur (in-depth interview). Selain data primer peneliti juga menggunakan data sekunder, yaitu data yang tidak langsung memberikan data kepada pengumpul data, misalnya lewat orang lain atau dokumen. Data sekunder dalam penelitian ini meliputi studi literatur dan dokumentasi.

Instrumen penelitian secara umum adalah suatu alat bantu yang digunakan oleh peneliti untuk mengukur atau mengumpulkan informasi kuantitatif maupun kualitatif sebagai bahan pengolahan dengan objek ukur yang sedang diteliti. Dalam proses penelitian, peneliti menggunakan pedoman wawancara dalam pengamatan di lapangan agar mendapatkan data-data pendukung yang relevan dengan permasalahan penelitian. Selain itu, peneliti menggunakan alat bantu pengumpulan data yaitu berupa buku catatan, kamera, pedoman wawancara dan perangkat observasi lain selama penelitian berlangsung. Menurut Sugiyno (2016) mengatakan bahwa analisis data dalam penelitian kualitatif dilakukan pada saat pengumpulan data berlangsung, dan setelah selesai pengumpulan data dalam periode tertentu. Pada saat wawancara, peneliti sudah melakukan analisis terhadap jawaban yang diwawancarai. Bila jawaban yang 
diwawancarai setelah dianalisis terasa belum memuaskan, maka peneliti akan melanjutkan pertanyaan lagi, sampai tahap tertentu, diperoleh data yang dianggap kredibel.

Analisis data yang digunakan dalam penelitain ini adalah Matriks Internal Factor Evaluation (IFE) dan External Factor Evaluationi (EFE). Analisis IFE merupakan alat strategi yang meringkas dan mengevaluasi kekuatan dan kelemahan sedangkan EFE merupakan evaluasi dari faktor eksternal berupa informasi perencanaan, pengembangan, potensi wisata, kerjasama masyarakat dengan pemerintah, dan permintaan wisatawan, yang semuanya terdapat pada daya tarik utama daya tarik wisata Bangsring Underwater (David \& David, 2015).

Tahapan teknik analisis terdiri dari tahap pengumpulan data (input stage), tahap pembobotan dan tahap pencocokan (The matching stage). Hasil dari proses analisis Matriks IFE dan EFE menjadi bahan pertimbangan untuk merumuskan strategi dengan menggunakan analisis SWOT. Analisis SWOT adalah suatu identifikasi dari berbagai faktor yang secara sistematis untuk merumuskan strategi, logika dasar yang dibangun dengan berusaha memaksimalkan kekuatan (strengths) dan peluang (opportunities) yang secara bersamaan dapat meminimalkan kelemahan (weaknesses) dan ancaman (threats) (Rangkuti, 2018).

Menurut David \& David (2015), dalam analisis SWOT yang telah dilakukan akan dibuat matriks SWOT yang mana akan menghasilkan empat sel kemungkinan alternatif strategi yaitu: (a) Strategi S-O (Strengths-Opportunities), (b) Strategi S-T (Strengths-Threats), (c) Strategi W-O
(Weaknesses-Opportunities), (d) Strategi W$\mathrm{T}$ (Weaknesses-Threats).

Pendekatan SWOT digunakan untuk mengkaji dan menganalisis potensi yang sesuai dengan kondisi dilapangan untuk dilakukan strategi pengembangan daya tarik wisata Bangsring Underwater berbasis masyarakat. Segala macam potensi yang dimiliki daya tarik wisata Bangsring Underwater dan selanjutnya dianalisis berdasarkan kekuatan atau kelemahan. Kelemahan dicari jalan keluarnya melalui pengadaan atau penggunaan strategi serta upaya-upaya pengembangan yang tepat dan sesuai sehingga peluang untuk mewujudkan pengembangan lebih terbuka. Sementara untuk ancaman-ancaman yang bisa ditimbulkan agar dapat diantisipasi sehingga bisa dihindari atau paling tidak diminimalisir.

Adapan rancangan penelitian yang dilakukan dalam penelitian ini adalah sebagai berikut:

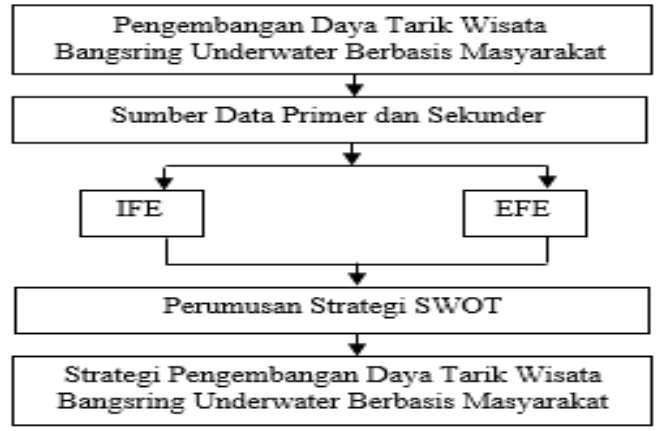

Gambar 1. Kerangka Pemikiran Penelitian Sumber: Analisis Peneliti, 2021

Terdapat 5 narasumber/ informan dalam penelitian ini dimana terdiri dari (1) Kepala Dinas Kebudayaan dan Pariwisata Kabupaten Banyuwangi., (2) Kepala Desa Bangsring., (3) Pengelola Wisata Bangsring Underwater (Pokdarwis Bangsring Underwater)., (4) Pedagang dan masyarakat sekitar wisata Bangsring Underwater., dan (5) Akademisi. 


\section{HASIL DAN PEMBAHASAN}

Pantai Bansgring, selaian terkenal dengan keindahan underwater juga memiliki bentangan alam yang indah, dengan pemandangan Selat Bali, Pulau Tabuhan, Pulau Menjangan dan pemandangan yang indah yaitu di waktu matahari terbit sehingga tepat untuk dijadikan sebagai tempat berwisata dengan keluarga, dimana kegiatan yang dapat dilakukan wisatawan yang berkunjung yaitu mulai dari kegiatan snorkeling, diving, bermain, jetsky, kano dan sekaligus belajar bagaimana untuk proses konservasi terumbu karang dan biota laut lainnya.

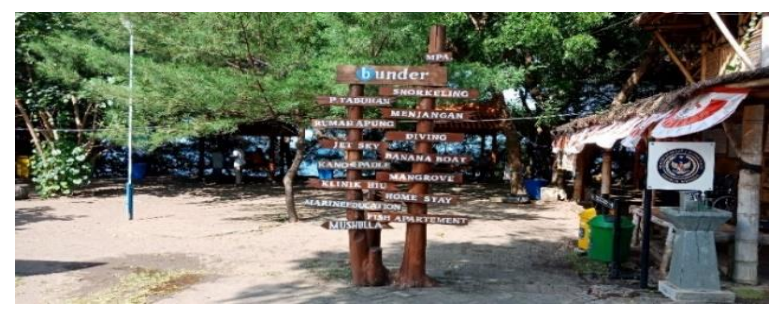

Gambar 2. Papan Informasi pada Daya Tarik Wisata Bangsring Underwater Sumber: Dokumentasi Peneliti, 2021

Berikut merupakan beberapa ragam aktivitas yang bisa dinikmati oleh wisatawan pada Daya Tarik Wisata Bangsring Underwater Banyuwangi, aktivitas tersebut merupakan andalan yang menjadi jualan dari daya tarik wisata ini.

\section{Rumah Apung}

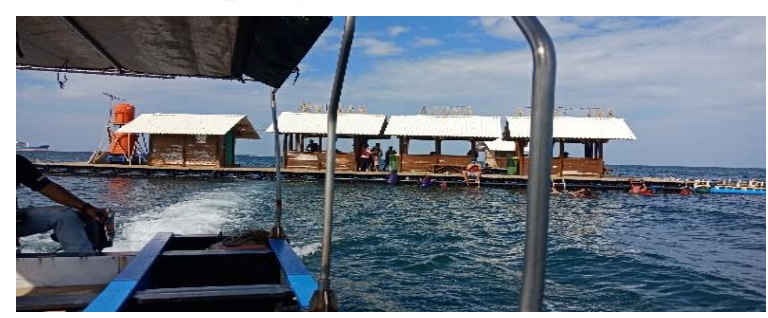

Gambar 3. Lokasi Rumah Apung

Sumber: Dokumentasi Peneliti, 2021

Rumah Apung Bangsring Underwater merupakan bangunan yang sengaja di dirikan di tengah laut pantai Bangsring yang berjarak
100 meter dari garis pantai Bangsring. Dimana dua bagian sisi kanan dan sisi kiri dari Rumah Apung diberi keranda sebagai tempat penangkaran ikan-ikan hias dan terumbu karang. Selain sebagai area penangkaran dan pelestarian bagi ikan-ikan dan terumbu karang, Rumah Apung Bangsring Underwater juga merupakan tempat dimana wisatawan yang berkunjung dapat melakukan kegiatan snorkeling dan diving untuk menikmati keindahan bawah laut.

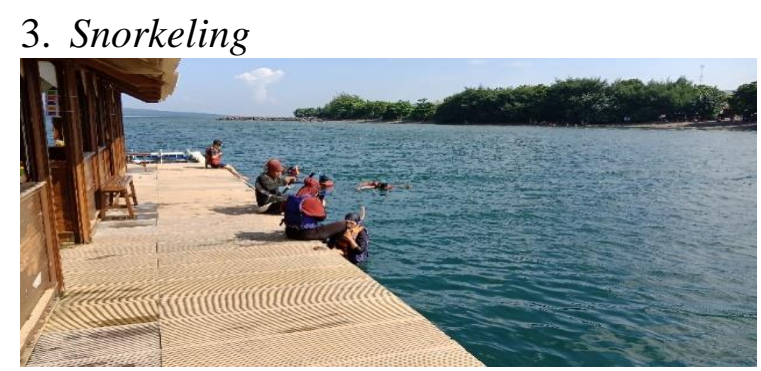

Gambar 4. Lokasi snorkeling

Sumber: Dokumentasi Peneliti, 2021

Berbeda halnya dengan beberapa pantai yang ada di Kabupaten Banyuwangi, daya tarik wisata Bangsring Underwater memiliki ombak yang tenang dan juga tidak terlalu besar sehingga wisatawan yang berkunjung dapat melakukan kegiatan snorkeling untuk melihat berbagai jenis ikan hias dan biota laut.

\section{Diving}

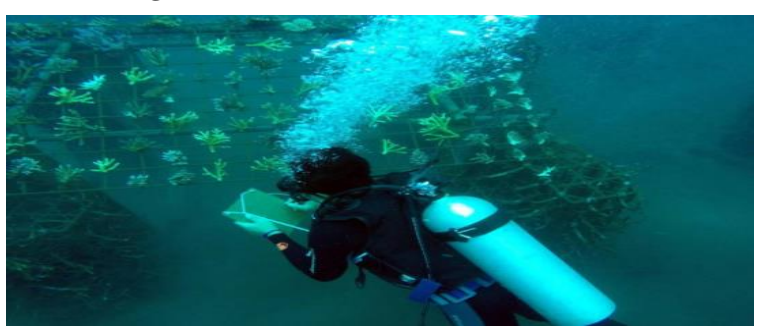

Gambar 5. Kegiatan Diving

Sumber: Dokumentasi Peneliti, 2021

Diving merupakan kegiatan menyelam dibawah permukaan air laut yang lebih dalam dengan bantuan alat pernapasan khusus 
berupa tabung oksigen, sepatu katak, dan kacamata khusus untuk berenang. Kegiatan diving yang biasa dilakukan di Bangsring Underwater diantaranya, melihat secara dekat keindahan bawah laut dan sekaligus belajar bagaimana proses untuk konservasi terumbu karang. Sehingga untuk melakukan kegiatan diving para wisatawan yang berkunjung harus di bantu alat khusus dan juga pemandu wisata Bangsring Underwater.

5. Wahana Jet Sky

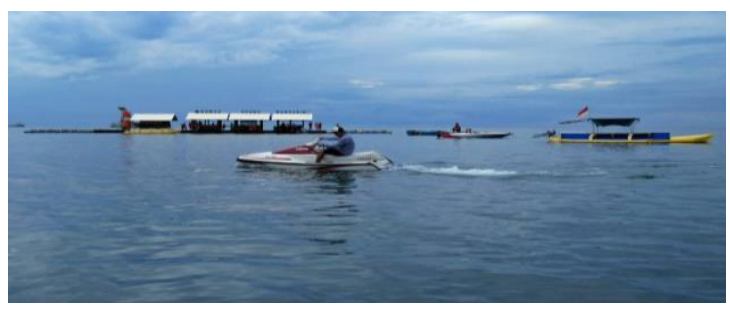

Gambar 5. Kegiatan Jet Sky

Sumber: Dokumentasi Peneliti, 2021

Selain kegiatan snorkeling dan diving, wisatawan yang berkunjung di daya tarik wisata Bangsring Underwater dapat melakukan kegiatan berwisata air lainnya. Seperti bermain jet sky yang disediakan dan di sewakan oleh pengelola pihak Bangsring Underwater.

6. Bermain Kano

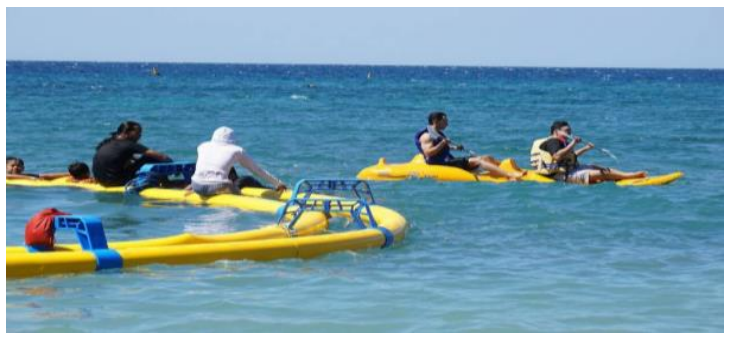

Gambar 6. Kegiatan Bermain Kano Sumber: Dokumentasi Peneliti, 2021

Kano merupakan sebuah perahu kecil dan sempit yang bisa digerakkan oleh manusia. Kano dapat di tunggangi maksimal oleh 3 orang dan untuk menggerakkan kano, pengayuh dapat duduk diatas kano, mengayuh, dan mengarahkan kano ke arah tujuan yang diinginkan. Bagi wisatawan yang berkunjung di Bangsring Underwater dan ingin mengelilingi area pantai selain dengan perahu, pengelola daya tarik Bangsring Underwater juga menyediakan penyewaan kano untuk para wisatawan yang ingin bersantai dan mengelilingi area pantai Bangsring Underwater.

7. Banyuwangi Underwater Festival

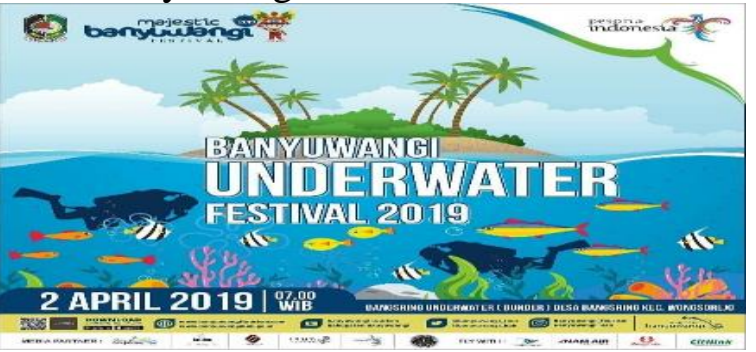

Gambar 7. Poster Banyuwangi Underwater Festival 2019

Sumber: Dokumentasi Peneliti, 2021

Banyuwangi Underwater Festival merupakan acara tahunan yang diselenggarakan pada daya tarik Bangsring Underwater di Kecamatan Wongsorejo Kabupaten Banyuwangi. Dimana acara ini memiliki keunikan yaitu dengan adanya para penari gandrung yang menari di bawah permukaan air laut pantai Bangsring.

\section{Faktor Pendukung}

Faktor pendukung dalam pengembangan kawasan wisata Bangsring Underwater merupakan suatu daya tarik bagi wisatawan untuk mengunjungi wisata Bangsring Underwater. Hal yang dapat dilakukan oleh pengelola dan masyarakat sekitar untuk mendukung kebutuhan wisatawan dengan cara menambah berbagai macam sarana prasarana. Program-program yang direncanakan oleh pihak pengelola daya tarik wisata untuk mendukung keberhasilan 
dalam mengembangkan daya tarik wisata Bangsring underwater.

Peran pemerintah, pengelola, masyarakat sekitar maupun pihak swasta terkait pengembangan wisata sangat dibutuhkan demi mensukseskan programprogram yang telah dilakukan maupun yang akan dilakukan. Kerjasama yang dilakukan oleh pengelola dan pemerintah Desa Bangsring maupun Kabupaten Banyuwangi hanya sebagai pelindung, pengawas dan pendukung kawasan wisata Bangsring Underwater.

\section{Faktor Penghambat}

Proses pengembangan kawasan wisata tentu saja tidak selamanya mengalami kemudahan, akan tetapi terdapat berbagai macam kendala yang harus dihadapi dan berpengaruh terhadap kemajuan perkembangan kawasan wisata. Berbagai macam aspek pada bidang pariwisata merupakan hal penting, supaya tidak terjadi penghambat dalam pengembangan daya tarik wisata.

Pada awal mulanya kawasan wisata Bangsring Underwater berkembang pesat, pola pikir beberapa masyarakat sekitar kawasan wisata menjadi salah satu faktor penghambat. Faktor yang mempengaruhi pola pikir masyarakat yaitu, masih adanya oknum masyarakat yang masih mencari ikan di sekitar area konservasi, minimnya sumber daya manusia, dan adanya wisatawan mancanegara yang berkunjung di wisata Bangsring Underwater dengan menggunakan pakaian yang kurang sopan. Hal tersebut yang menjadi alasan bagi beberapa masyarakat Desa Bangsring sulit menerima adanya kegiatan kepariwisataan. Akan tetapi seiring berjalannya waktu sedikit demi sedikit masyarakat sekitar bisa menerima dan mendukung adanya kegiatan kepariwisataan di Desa Bangsring. Kenyamanan masyarakat sangatlah berperan untuk melakukan kegiatan kepariwisataan, sehingga kerjasama antara pihak pengelola wisata dan masyarakat setempat sangatlah diperlukan.

Hal tersebut di atas sangat diperlukan selain kerjasama juga faktor pendanaan juga menjadi hal yang perlu dalam pengelolaan daya tarik wisata (Mulyana \& Yulianto, 2019)

\section{Faktor Internal Daya Tarik Wisata Bangsring Underwater}

\section{A. Kekuatan}

1. Keindahan Alam

Bangsring Underwater merupakan merupakan salah satu jenis wisata bahari yang memiliki keindahan alam bawah laut yang masih terjaga dengan baik. Dimana keindahan alam wisata Bangsring Underwater dapat menjadi daya tarik dan memberikan kepuasan dan pengalaman baru bagi wisatawan yang berkunjung. Keunikan lain yang ada di Bangsring underwater yaitu bagi wisatawan yang berkunjung juga bisa menikmati 2 daya tarik wisata lainnya yang disuguhkan seperti, Pulau Tabuhan dan Pulau Menjangan.

\section{Melestarikan Alam (Konservasi Terumbu} Karang dan Biota Laut)

Bangsring Underwater merupakan merupakan salah satu jenis wisata yang berbasis konservasi terumbu karang dan biota laut lainnya yang tujuannya tidak lain hanya untuk tetap menjaga kelestarian lingkungan 
Bangsring underwater. Dari kegiatan konservasi yang dilakukan oleh pihak pengelola dan masyarakat juga mendapat tanggapan positif dari pemerintah Kabupaten Banyuwangi.

3. Aksesibilitas Yang Menunjang

Dalam (Suwena \& Widyatmaja, 2017) menjelaskan bahwa terdapat faktor penentu keberhasilan dan digunakan untuk menilai besar kecilnya potensi yang dimiliki suatu destinasi pariwisata yaitu atraksi wisata, fasilitas wisata dan aksesibilitas. Berdasarkan hal tersebut dapat dikatakan akses merupakan salah satu faktor penting dalam pembentukan sebuah wisata. Akses yang harus dilalui para wisatawan yang ingin menuju Bangsring Underwater sendiri terbilang sangat mudah dan memadai karena sepanjang jalannya sudah beraspal halus. Hal ini dikarenakan lokasi Bangsring Underwater yang berada di pinggir jalur pantura dimana jalur yang menghubungkan antara Kabupaten Banyuwangi dan Kabupaten Situbondo.

4. Masyarakat Sekitar Yang Ikut Berpartisipasi Dan Tergabung Dalam Kelompok Sadar Wisata (POKDARWIS)

Bangsring Underwater memiliki organisasi yang didirikan dengan cara swadaya masyarakat dan disosialisasikan kepada tokoh masyarakat dan para nelayan untuk membentuk suatu kelompok sadar wisata yang disebut dengan nama Samudra Bhakti. Organisasi kelompok sadar wisata Samudra Bhakti yang menghasilkan sub organisasi seperti: Koperasi Usaha Bersama, Zona Perlindungan Bersama, dan Pengelolaan Air. Karena kesadaran dari masyarakat untuk menjadi pelaku usaha dan untuk mengelola Bangsring Underwater yang sudah disediakan oleh pemerintah desa. Para kelompok nelayan yang ikut serta dalam mengelola daya tarik wisata Bangsring juga sangat aktif, selama ini daya tarik wisata Bangsring Underwater bisa berjalan sesuai harapan.

\section{B. Kelemahan}

1. Sumber Daya Manusia

Rendahnya sumber daya manusia dan kurang kompetennya sumber daya manusia di wisata Bangsring Underwater menjadi kelemahan tersendiri di daya tarik wisata Bangsring Underwater. Hal ini terlihat dari manajamen tata kola daya tarik yang masih ditemui kerusakan-kerusakan dan sampah yang tidak terkontrol. Sumber daya manusia idelanya menjadi perhatian guna meningkatkan kualitas tata kelola daya tarik wisata (Nurcahyo \& Yulianto, 2019)

\section{Keamanan dan Kenyamanan}

Dalam (Suwena \& Widyatmaja, 2017)menjelaskan bahwa terdapat faktor penentu keberhasilan dan digunakan untuk menilai besar kecilnya potensi yang dimiliki suatu destinasi pariwisata yaitu atraksi wisata, fasilitas wisata dan aksesibilitas. Maka dari itu fasilitas merupakan salah satu faktor penting yang dapat mendukung kenyamanan serta memberikan perasaan baik kepada para wisatawan dalam menikmati sebuah destinasi wisata, baik wisata alam maupun buatan. Pada daya tarik Bangsring Underwater sendiri masih terdapat kelemahan tentang pengelolaan fasilitas seperti, Toilet umum yang diperlukan pembenahan dan kebersihannya masih belum maksimal dan lahan parkir luasnya sudah 
memadai namun apabila siang hari kondisinya sangat panas sedangkan tidak ada atap peneduh untuk area parkirnya.

3. Kurangnya Kolaborasi Dengan Unsur Kemitraan Pariwisata

Menurut Soebagyo (2012) pengembangan perlu dilakukan di suatu kawasan wisata agar kawasan tersebut memiliki daya saing, pengembangan pariwisata yang menunjang pertumbuhan ekonomi dapat dilakukan dengan salah satunya melakukan kegiatan promosi yang beragam, kegiatan promosi dan menjalin kerjasama dengan unsur kemitraan juga harus dilakukan. Media sosial saat ini menjadi sarana promosi yang utama untuk berbagi informasi yang berupa audio, gambar atau video melalui perangkat elektronik antara satu orang ke orang lain. Selain itu, media sosial sebagai salah satu media yang tidak dapat dilepaskan dalam kehidupan sehari hari. Berdasarkan hal tersebut pengelola Bangsring Underwater juga memanfaatkan media sosial dalam kegiatan promosi, namun kerjasama dengan unsur kemitraan pariwisata seperti biro perjalanan wisata yang telah dilakukan pihak Bangsring Underwater masih belum maksimal yang bertujuan untuk membantu memasarkan serta meningkatkan kunjungan di daya tarik wisata Bangsring Underwater.

Faktor Eksternal Daya Tarik Wisata Bangsring Underwater

A. Peluang

1. Menciptakan Lapangan Pekerjaan Bagi Masyarakat Sekitar

Menurut Soebagyo

pengembangan perlu dilakukan di suatu kawasan wisata agar kawasan tersebut memiliki daya saing, pengembangan pariwisata yang menunjang pertumbuhan ekonomi dapat dilakukan dengan salah satunya mengajak masyarakat sekitar daerah tujuan wisata (DTW) agar menyadari peran, fungsi, dan manfaat dari pariwisata serta merangsang mereka untuk memanfaatkan peluang yang tercipta bagi banyak kegiatan yang dapat menguntungkan secara ekonomi.

Dahulu Bangsring Underwater hanyalah pantai yang rusak karena adanya kegiatan para nelayan yang mencari ikan dengan cara pengeboman dan potasium sehingga terjadinya kerusakan yang cukup parah pada ekosistem bawah laut, namun sekarang sudah dirubah menjadi daya tarik wisata yang dapat dinikmati setiap hari karena keindahan alam bawah lautnya. Pemerintah Desa bersama dengan beberapa kelompok nelayan yang sadar akan lingkungan yang tergabung dalam kelompok nelayan Samudra Bhakti dan telah bekerjasama dalam pengembangan Bangsring Underwater.

2. Lokasi Yang Strategis Dekat dengan Pelabuhan Penyeberangan, Stasiun Kereta Api

Daya tarik wisata Bangsring Underwater yang berada di pinggir jalan, dekat dengan stasiun kereta api, pelabuhan penyeberangan Ketapang dan juga tidak jauh dari pusat Kota Banyuwangi lokasinya berjarak kurang lebih $23 \mathrm{~km}$. Lokasi wisatanya yang tergolong strategis karena berada di tepi jalur pantura yang menghubungkan Kabupaten Banyuwangi dan Kabupaten Situbondo. Selain itu, yang mana kita ketahui Bangsring Underwater 
juga merupakan tempat penyebrangan ke Pulau Tabuhan dan Pulau Menjangan dimana kedua daya tarik wisata tersebut merupakan daya tarik wisata yang cukup diminati oleh para wisatawan lokal maupun mancanegara.

\section{Adanya Event Banyuwangi Underwater Festival}

Bangsring Underwater juga memiliki acara tahunan yakni Banyuwangi Underwater Festival yang diadakan setiap satu tahun sekali. Festival ini bisa dikatakan sebagai icon dari Bangsring Underwater yang dapat menarik minat kunjungan wisatawan untuk datang ke daya tarik wisata Bangsring Underwater. Meskipun diadakan setiap satu tahun sekali festival ini nantinya juga akan berpengaruh bagi Bangsring Underwater dari segi promosi yang terus berkelanjutan dan juga naiknya kunjungan wisatawan.

\section{Kemajuan Teknologi Informasi dan Komunikasi}

Kemajuan teknologi informasi dan komunikasi sangat berpengaruh kepada beberapa bidang termasuk pariwisata, dengan adanya teknologi informasi promosi digital akan lebih maksimal. Hal ini diperlukan untuk memperkenalkan mulai dari, daya tarik wisata, sarana dan prasarana, akses dan transportasi, paket wisata yang ditawarkan, biaya, rute dan jarak, serta apapun yang terkait dengan pariwisata. Pemanfaatan teknologi informasi yang dapat digunakan adalah E-Tourism, yaitu media yang memberikan informasi tentang daya tarik wisata serta segala fasilitas pendukungnya. Oleh karena itu, pemanfaatan teknologi informasi dengan pengembangan sistem $E$ Tourism merupakan hal mutlak yang harus segera diterapkan oleh pengelolaan Bangsring Underwater.

\section{B. Ancaman}

1. Kurangnya Kesadaran Masyarakat Dalam Menjaga Kebersihan dan Kelestarian Lingkungan

Menjaga kebersihan dan kelestarian lingkungan di suatu destinasi pariwisata merupakan tanggung jawab bersama baik itu masyarakat, wisatawan, serta pemerintah. Menciptakan lingkungan yang bersih bagi berlangsungnya kegiatan kepariwisataan yang mampu memberikan layanan higienis bagi wisatawan. Salah satu bentuk aksi dari menjaga kebersihan dan kelestarian lingkungan di destinasi pariwisata termasuk aktivitas kepariwisataan diantaranya adalah dengan tidak membuang sampah/limbah sembarangan, turut menjaga kebersihan sarana dan lingkungan daya tarik wisata.

Salah satu ancaman yang ada di Bangsring Underwater adalah masih adanya beberapa masyarakat dan wisatawan yang berkunjung yang belum sadar akan menjaga kebersihan lingkungan. Kegiatan merusak lingkungan yang sering terjadi adalah masih banyaknya wisatawan dan masyarakat yang membuang sampah sembarangan yang seharusnya di buang di tempat sampah yang telah disediakan dan beberapa masyarakat sekitar yang mencari ikan di area konservasi.

\section{Pandemi Covid-19}

Adanya pandemi Covid-19 memberikan dampak yang sangat besar terhadap semua sektor industri khususnya juga industri pariwisata. Banyak sekali sektor pariwisata yang mengalami penurunan yang signifikan. Seperti halnya dengan daya tarik 
wisata Bangsring Underwater yang mengalami penurunan wisatawan yang cukup drastis. Pelaku usaha seperti warung, guide dan penyewaan perahu untuk penyeberangan ke Pulau Tabuhan dan Pulau Menjangan juga mengalami dampaknya akibatnya penghasilan yang diperoleh pelaku usaha semakin menurun dan juga ada beberapa yang memilih mencari mata pencaharian lain.

Adanya pandemi covid 19 yang menjadi salah satu ancaman maka dengan ini sangat diperlukan pariwisata bernasis kesehatan atau health tourism sebagai salah satu upaya menciptakan suasana aman dan nyaman bagi wisatawan (Nieamah \& Purwoko, 2021)

3. Potensi Bencana Alam (Banjir, Gempa Bumi dan Tsunami)

Bangsring Underwater termasuk wisata alam, tidak dapat dipungkiri bahwa potensi bencana alam akan terjadi sewaktu-waktu tergantung dengan situasi dan kondisi alam. Maka kemungkinan akan ada resiko bencana alam seperti gempa bumi dan banjir apabila faktor cuaca alam yang kurang baik di daya tarik wisata Bangsring Underwater.

\section{SRATEGI PENGEMBANGAN}

Pengembangan pariwisata berbasis masyarakat di daya tarik wisata Bangsring Underwater memiliki berbagai potensi yang sangat ideal untuk maksimalkan dalam bentuk atraksi termasuk beberapa hambatan formulasi strategi tepat dan efektif.

Strategi merupakan suatu proses penentuan nilai pilihan dan pembuatan keputusan dalam pemanfaatan sumber daya yang menimbulkan suatu komitmen bagi organisasi yang bersangkutan kepada tindakan-tindakan yang mengarah pada masa depan.

Mengacu pada Undang - Undang Nomor 10 Tahun 2009 menyebutkan bahwa Tujuan Kepariwisataan Indonesia adalah sebagai berikut; (a) Meningkatkan pertumbuhan ekonomi; (b) Meningkatkan kesejateraan rakyat; (c) Menghapus kemiskinan; (d) Mengatasi pengangguran; (e) Melestarikan alam, lingkungan dan sumberdaya; (f) Memajukan kebudayaan; (g) Mengangkat citra bangsa; (h) Memupuk rasa cinta tanah air; (i) Memperkukuh jatidiri dan kesatuan bangsa; dan (j) Mempererat persahabatan antar bangsa.

Dengan demikian, pengembangan pariwisata berbasis masyarakat sangat ideal di kembangkan guna dapat meningkatkan kesejateraan rakyat serta mengatasi pengangguran terutama di desa - desa termasuk di daya tarik wisata Bangsring Underwater yang terletak di Desa Bangsring Kecamatan Wongsorejo Kabupaten Banyuwangi.

Kondisi lingkungan internal dan eksternal daya tarik wisata Bangsring Underwater sebagai daya tarik wisata berkelanjutan dan pariwisata berbasis masyarakat terdiri dari faktor - faktor yang dapat menjadi kekuatan, kelemahan, peluang dan ancaman. Berikut adalah beberapa faktor yang dapat menjadi kekuatan diantaranya adalah: (1) Keindahan Alam, Melestarikan Alam, (3) Aksesibilitas yang menunjang, dan (4) Kelompok Sadar Wisata. Kemudian yang dapat menjadi kelemahannya adalah: (1) Sumber Daya Manusia, (2) Keamanan dan Kenyamanan, 
(3) Kurangnya Kolaborasi dengan unsur kemitraan pariwisata.

Faktor yang dapat menjadi kekuatan dan kelemahan tersebut merupakan hal yang perlu dipertimbangan dalam pengembangan pariwisata berbasis masyarakat di daya tarik wisata Bangsring Underwater dan selain kedua faktor tersebut juga, terdapat juga faktor - faktor yang dapat menjadi peluang serta ancaman dalam pengembangan pariwisata di daya tarik wisata Bangsring Underwater. Berikut adalah beberapa faktor yang dapat menjadi peluang diantaranya adalah: (1) Menciptakan lapangan pekerjaan bagi masyarakat sekitar, (2) Memiliki lokasi yang strategis dekat dengan pelabuhan penyeberangan dan stasiun kereta api, (3) Event Banyuwangi Underwater festival, (4) Kemajuan teknologi, informasi dan komunikasi. Sedangkan faktor yang menjadi ancamannya adalah: (1) Kurangan kesadran masyarakat dalam menjaga kebersihan dan kelestarian lingkungan, (2) Pandemi Covid19, (3) Potensi bencana alam seperti; banjir, gempa bumi, dan tsunami.

Kondisi lingkungan internal dan eksternal menjadi aspek yang ideal untuk memformulasikan strategi dalam pariwisata berbasis masyarakat di daya tarik wisata Bangsring Underwater. Beradasarkan kondisi lingkungan internal dan eksternal diperoleh strategi yang tepat efektif untuk diterapkan dalam pengembangan pariwisata berbasis masyarakat di daya tarik wisata Bangsring Underwater yang berkelanjutan dan berdaya saing. Melalui pendekatan deskriptif kualitatif dan analisi matriks SWOT (Strengths, Weakness, Opportunities, and Threats) dirumuskan strategi alternatifnya. Analisis serta kajian terhadap potensi dan kendala yang menghambat pengembangan pariwisata berbasis masyarakat di daya tarik wisata

Bangsring Underwater yang berkelanjutan dan berdaya saing menunjukan bahwa, diperlukan adanya startegi yang tepat untuk diterapkan dalam pengembangan tersebut. Melalui pendekatan deskriptif kualitatif dan analisis SWOT tersebut, ditemukan beberapa strategi alternatif yang dapat diterapkan.

Strategi-stategi tersebut disususn berdasarkan pertimbangan tentang kekuatan, kelemahan, peluang dan ancaman.

Adapun strategi yang dapat diterapkan dalam pengembangan pariwisata berbasis masyarakat di daya tarik wisata Bangsring Underwater yang berkelanjutan dan berdaya saing adalah sebagai berikut;

Strategi Strength-Opportunity (S-O) merupakan strategi yang menggunakan kekuatan untuk memanfaatkan peluang, sehingga menghasilakan strategi pengembangan daya tarik wisata dan strategi promosi daya tarik wisata, guna menujang pengembangan yang lebih ideal.

Kekuatan yang dimilikinya harus digunakan dengan semaksimal mungkin agar dapat memanfaatkan segala peluang yang ada dengan sebaik - baiknya.

$$
\text { Strategi Strength-Threat }
$$
merupakan strategi yang menggunakan kekuatan untuk mengatasi ancaman, dimana strategi yang dihasilkan dalam penelitian ini adalah strategi meningkatan kualitas lingkungan dan strategi pengembangan daya tarik wisata berkelanjutan.

Strategi Weakness-Opportunity (W-O) meminimalkan kelemahan untuk memanfaatkan peluang, ini merupakan 
strategi yang sangat penting digunakan dalam pengembangan pariwisata berbasis masyarakat. Sehingga strategi yang ditemukan dalam penelitian ini adalah Strategi meningkatkan keamanan dan kenyamanan.

Strategi Weakness-Threat (W-T) merupakan strategi yang meminimalkan kelemahan dan menghindari ancaman merupakan strategi yang mendukung dalam pariwisata berbasis masyarakat di daya tarik wisata Bangsring Underwater yang berkelanjutan dan berdaya saing, strategi ini menghasilkan strategi pengembangan sumberdaya manusia dan strategi meningkatkan kerjasama dengan unsur kemitraan pemerintah maupun swasta.

Adapun secara umum digambarkan dalam bentuk tabel berikut:

a. Kondisi Lingkungan Internal

Tabel. 1 Matriks IFE daya tarik wisata Bangsring Underwater

\begin{tabular}{|c|c|c|c|}
\hline $\begin{array}{l}\text { INTERNAL } \\
\text { Kekuatan }\end{array}$ & B & $\mathbf{R}$ & $\mathbf{S}$ \\
\hline A. Keindahan Alam & 0.15 & 3 & 0.45 \\
\hline $\begin{array}{l}\text { B. Melestarikan } \\
\text { Alam ( } \\
\text { Konservasi } \\
\text { Terumbu Karang } \\
\text { dan Biota Laut) }\end{array}$ & 0.16 & 4 & 0.64 \\
\hline $\begin{array}{l}\text { C. Aksesibilitas } \\
\text { Yang Menunjang }\end{array}$ & 0.14 & 3 & 0.43 \\
\hline $\begin{array}{l}\text { D. Masyarakat } \\
\text { Sekitar Yang Ikut } \\
\text { Berpartisipasi } \\
\text { Dan Tergabung } \\
\text { Dalam Kelompok } \\
\text { Sadar Wisata } \\
\text { (POKDARWIS) }\end{array}$ & 0.15 & 4 & 0.60 \\
\hline Total Kekua & & & 2.12 \\
\hline
\end{tabular}

\begin{tabular}{lllll}
\hline \multicolumn{2}{l}{ Kelemahan } \\
E. $\begin{array}{l}\text { Sumber Daya } \\
\text { Manusia }\end{array}$ 0.14 & 2 & 0.29 \\
F. $\begin{array}{l}\text { Keamanan Dan } \\
\begin{array}{l}\text { Kenyamanan } \\
\text { G. }\end{array}\end{array}$ & 0.15 & 1 & 0.15 \\
& $\begin{array}{l}\text { Kurangnya } \\
\text { Kolaborasi } \\
\text { Dengan Unsur } \\
\text { Kemitraan } \\
\text { Pariwisata }\end{array}$ & 0.10 & 2 & 0.20 \\
\hline \multicolumn{1}{c}{ Total Kelemahan } \\
\hline Total \\
\hline
\end{tabular}

Keterangan:

$\mathrm{B}=$ Bobot; R=Rating; $\mathrm{S}=$ Skor

b. Kondisi Lingkungan Ekternal

Tabel. 2 Matriks IFE daya tarik wisata Bangsring Underwater

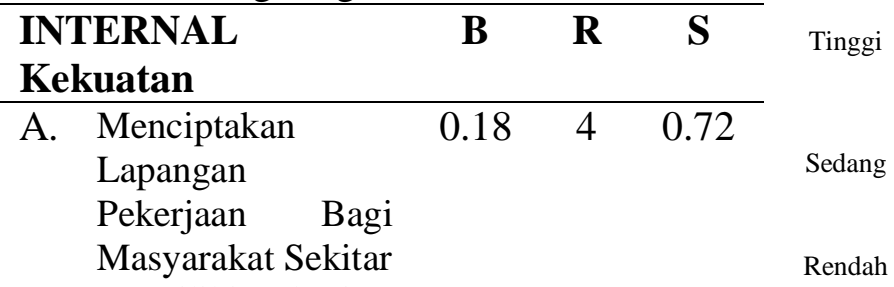
B. Memiliki Lokasi $\quad 0.16 \quad 3 \quad 0.48$
Yang Strategis

Dekat dengan

Pelabuhan

Penyeberangan,

Stasiun Kereta Api
C. Adanya Event
$\begin{array}{lll}0.15 & 3 & 0.45\end{array}$
Banyuwangi
Underwater
Festival

$\begin{array}{llll}\text { D. Kemajuan } & 0.14 & 3 & 0.41\end{array}$

Teknologi

Informasi dan

Komunikasi

Total Peluang $\quad 2.06$

\section{Kelemahan}

$\begin{array}{lllll}\text { E. } & \text { Kurangnya } & 0.17 & 2 & 0.33 \\ \text { Kesadaran } & & & \\ \text { Masyarakat } & & & \end{array}$


Dalam Menjaga

Kebersihan dan

Kelestarian

Lingkungan

F. Pandemi Covid- $0.09 \quad 1 \quad 0.09$ 19

G. Potensi Bencana $0.11 \quad 1 \quad 0.11$ Alam (Banjir, Gempa Bumi dan Tsunami)

\begin{tabular}{ccc}
\hline \multicolumn{2}{c}{ Total Ancaman } & 0.53 \\
\hline Total & 1.00 & 2.60 \\
\hline
\end{tabular}

c. Matriks Internal Eksternal (IE)

atriks IFE dan EFE yang telah diberikan bobot dan peringkat serta telah memiliki skor rata-rata tertimbang, kemudian akan digabung pada matriks internal dan eksternal. Skor bobot IFE pada sumbu X dan skor bobot EFE pada sumbu Y.

\begin{tabular}{|c|c|c|c|}
\hline 4,0 & Kuat & Rata-rata & Rendah \\
\hline Tingegi & I & II & III \\
\hline 3,0 & & & \\
\hline $\begin{array}{l}\text { Sedeng } \\
2,0\end{array}$ & IV & V & VI \\
\hline $\begin{array}{r}\text { Refdath } \\
1,0\end{array}$ & VII & VIII & IX \\
\hline
\end{tabular}

Gambar 8. Matriks Internal-Eksternal (IE) Sumber: Analisis Peneliti, 2021

Berdasarkan skor pada matriks IE, dengan nilai $\mathrm{IFE}=2,76$ dan $\mathrm{EFE}=2,60$ maka posisi daya tarik wisata Bangsring Underwater berada pada kuadran V yaitu Hold and maintain. Strategi yang dapat dijalankan dijelaskan oleh David (2015), untuk yang berada pada sel III, V, VII dapat dikelola paling baik dengan strategi ditahan dan dijaga (penetrasi pasar dan pengembangan produk) merupakan strategi yang umum digunakan.

Terkait dengan uraian tersebut di atas maka idealnya menyediakan atau menambah infrastruktur untuk mendukung kegiatan pariwisata berbasis ekowisata, membuat atau menambah produk pariwisata ramah lingkungan, melakukan pelatihan ekowisata untuk sumber daya manusia pengelola Bangsring Underwater, bekerjasama dengan semua pihak serta berperan aktif dalam penyelenggaraan kegiatan pariwisata berkelanjutan dengan pelibatan masyarakat secara aktif (Rohman, Susanto, \& Kiswantoro, 2020)

\section{d. Analisis SWOT}

Berdasarkan analisis lingkungan internal dan eksternal di atas, maka digunakan analisis SWOT untuk mengetahui strategi pengembangan daya tarik wisata Bangsring Underwater.

Berikut ini strategi SWOT Daya Tarik Wisata Bangsring Underwater:

\section{Strategi S-O}

Strategi yang menggunakan kekuatan untuk memanfaatkan peluang:

a) Strategi Pengembangan Daya Tarik Wisata (S1,S2,S3,S4,O1,O2,O3,O4)

b) Strategi Promosi Daya Tarik Wisata $(\mathrm{S} 1, \mathrm{~S} 2, \mathrm{O} 3, \mathrm{O} 4)$

\section{Strategi W-O}

Strategi yang meminimalkan kelemahan untuk memanfaatkan peluang:

a) Strategi Meningkatkan Keamanan dan Kenyamanan (W1,W2,O1) 


\section{Strategi S-T}

Strategi yang menggunakan kekuatan untuk mengatasi ancaman:

a) Strategi Meningkatkan Kualitas Lingkungan (S1,S2,T1)

b) Strategi Pengembangan Pariwisata Berkelanjutan (S1,S2,S4,T1,T2)

\section{Strategi W-T}

Strategi meminimalkan Kelemahan untuk menghindari ancaman:

a) Strategi Pengembangan Sumber Daya Manusia (W1,T1)

b) Strategi Meningkatkan Kerjasama Dengan Unsur Kemitraan Pemerintah Maupun Swasta (W3,T,2,T3)

\section{KESIMPULAN}

Adapun kesimpulan yang dapat ditarik dalam penelitian ini adalah sebagai berikut:

1. Daya tarik wisata Bangsring Underwater memiliki faktor pendukung yang berupa kerjasama antara pengelola daya tarik wisata dengan masyarakat sekitar, pemerintah Desa Bangsring dan pemerintah Kota Banyuwangi dalam mendukung pengembangan daya tarik wisata Bangsring Underwater dan juga faktor penghambat yang berupa minimnya sumber daya manusia dan beberapa masyarakat lokal sekitar yang belum bisa menerima adanya kegiatan kepariwisataan di Desa Bangsring.

2. Bangsring Underwater memiliki Potensi yang dapat dikembangkan seperti; menjadi salah satu wisata berbasis masyarakat, dikelola langsung oleh kelompok sadar wisata Samudra Bhakti (Pokdarwis), menciptakan lapangan pekerjaan bagi masyarakat lokal Desa Bangsring dan menjadi salah satu event festival underwater di Kabupaten Banyuwangi.

3. Didapatkan 7 strategi pengembangan yang dapat dilakukan dalam pengembangan daya tarik wisata Bangsring Underwater berbasis masyarakat diantaranya; diantaranya Strategi Pengembangan Daya Tarik Wisata, Strategi Promosi Daya Tarik Wisata, Strategi Meningkatkan Keamanan dan Kenyamanan, Strategi Meningkatkan Kualitas Lingkungan, Strategi Pengembangan Pariwisata Berkelanjutan, Strategi Pengembangan Sumber Daya Manusia, serta Strategi Meningkatkan Kerjasama Dengan Unsur Kemitraan Pemerintah Maupun Swasta.

\section{DAFTAR PUSTAKA}

David, F. R., \& David, F. R. (2015). Manajemen Strategik. Jakarta: Salemba Empat.

Kabupaten Banyuwangi. (2021). Data Pariwisata. Retrieved Februari 18, 2021, from banyuwangikab.go.id: https://banyuwangikab.go.id/profil/p ariwisata.html

Kanom, \& Randhi, N. D. (2020). Pengembangan Taman Wisata Alam Gunung Tunak Sebagai Destinasi Pariwisata Berkelanjutan. Jurnal Ilmiah Pariwisata, 25(2), 84-98. 
Kanom, \& Zazilah, A. N. (2019). Strategi Pengembangan Pariwisata Berbasis Masyarakat di The Mandalika Kuta Lombok. Bina Ilmiah, 14(4), 25092524.

Kanom, Nurhalimah, \& Darmawan, R. N. (2020). Recovery Pariwisata Banyuwangi Pasca Covid 19. Bina Ilmiah, 15(3), 10-20.

Nieamah \& Purwoko. (2021). Strategi Pengembangan Health Tourism di Yogyakarta. Jurnal of Tourism and Economic, 38-46.

Nurcahyo \& Yulianto. (2019). Pengembangan Daya Tarik Wisata Kunjungan Melalui Wahana Edukasi Musium Pura Pakualam Yogyakarta. Jurnal Of Tourism and Economic, 5765.

Mulyana \& Yulianto. (2019). Strategi Pengembangan Pesisir Pantai Selatan Sebagai Objek Pariwisata Kabupaten Kulon Progo. Jurnal Of Tourism and Economic, 39-47.

Muliarta, I. K. (2020). Strategi Pengembangan Pariwisata Berbasis
Masyarakat Pada Desa Wisata Nyambu. Journal of Applied Management Studies (JAMMS), 1(2), 152-166.

Rangkuti, F. (2018). Teknik Membedah Kasus Bisnis Analisis SWOT. Jakarta: PT Gramedia Pustaka Utama.

Rohman, Susanto, \& Kiswantoro. (2020). Strategi Pengelolaan Pantai Banyu Tibo Berbasis Ekowisata Di Kabupaten Pacitan Jawa Timur. Jurnal Of Tourism and Economic, 135-144.

Soebagyo. (2012). Strategi Pengembangan Pariwisata Di Indonesia. Liquidity, 1(1), 153-158.

Sugiyno. (2016). Metode Penelitian Kuantitatif, Kualitatif dan $R \& D$. Bandung: Alfabeta.

Sumantri, A. (2011). Metode Penelitian Kesehatan. Jakarta: Kencana Prenada Media Grup.

Suwena, I. K., \& Widyatmaja, I. G. (2017). Pengetahuan Dasar Ilmu Pariwisata. Bali: Penerbit Pustaka Larasan. 